\title{
ANALISIS SISTEM INFORMASI AKUNTANSI PENDAPATAN (Studi Kasus Pada PT. Maxindo Karya Selaras Bengkulu)
}

\author{
Herlin, Nani Halima Zahara, Sepri Yanti \\ Program Studi Manajemen Fakultas Ekonomi Universitas Dehasen Bengkulu \\ Herlin_olin81@yahoo.com
}

\begin{abstract}
ABSTRAK
Herlin, Nani Halima Zahara, Sepri Yanti; Tujuan penelitian ini adalah untuk mengetahui penerapan sistem informasi akuntansi pendapatan pada PT. Maxindo Karya Selaras Kota Bengkulu. Metode analisis yang digunakan adalah metode komparatif.

Hasil penelitian menunjukkan bahwa dalam penerapan sistem informasi akuntansi pendapatan pada PT. Maxindo Karya Selaras Kota Bengkulu terdapat kesesuaian pada sistem penerimaan pendapatan, fungsi yang terkait, dokumen yang digunakan, catatan akuntansi yang digunakan, dan jaringan prosedur sistem penerimaan pendapatan dengan teori Mulyadi. Karena pada PT. Maxindo Karya selaras Kota Bengkulu terdapat proses pendapatan yang dimulai dari pesanan batu bara dari pembeli, pengiriman dan penagihan sudah berjalan dengan baik.
\end{abstract}

\section{ABSTRACT}

Herlin, Nani Halima Zahara, Sepri Yanti; The purpose of this study was to determine the application of the accounting information system of income at PT. Maxindo Karya Selaras Bengkulu City. The analytical method used was the comparative method.

The results showed that in the application of accounting information system of income at PT. Maxindo Karya Selaras Bengkulu City suitability reception system revenue, related functions, which are used documents, accounting records are used, and the network system procedures receipt of revenue by Mulyadi theory. Because at PT . Maxindo Karya Selaras Bengkulu City there is a process of income starting from coal orders from buyers, shipping and billing is already well underway.

Key Words: Accounting Information System, Revenue.

\section{LATAR BELAKANG}

Informasi sangat penting bagi setiap perusahaan dalam mengarahkan dan memperlancar kegiatan sehari-hari karena dapat membantu pengambilan suatu keputusan. Sistem informasi diterapkan dalam perusahaan bertujuan untuk menyajikan informasi guna mendukung pengambilan keputusan, menyajikan informasi guna mendukung operasi harian, dan menyajikan informasi yang berkenaan dengan kepengurusan. Informasi tidak kalah pentingnya dengan sumber daya lain yang dimiliki perusahaan seperti peralatan, persediaan atau pabrik karena informasi yang akurat akan sangat mempengaruhi suatu perusahaan untuk maju dan berkembang dalam dunia usaha seperti sekarang ini. Penyebab sistem informasi sering bermasalah diantaranya adalah waktu, sistem lingkungan yang berubah, perubahan prosedur operasional. Sedangkan permasalahan sistem informasi yang berkaitan dengan karakteristik informasi adalah relevansi, keakuratan, yang memiliki faktor kelengkapan, kebenaran, dan keamanan, tepat waktu, sumber daya dan biaya, efisiensi, apakah ada kegagalan dalam perencanaan, dapat dipercaya serta kegunaannya.Suatu perusahaan sering kali memiliki banyak transaksi dalam usahanya. Oleh karena itu sangat diperlukannya sebuah sistem yang efisien dan efektif untuk menangani transaksi-transaksi untuk mempermudah pemrosesan siklus transaksi, siklus pengeluaran, siklus produksi, dan siklus pendapatan.

Sistem informasi akuntansi pendapatan merupakan hal yang sangat penting dalam menjalankan proses bisnis dalam menganalisis data transaksi di dalam perusahaan. Sistem informasi akuntansi pendapatan dimaksudkan agar perusahaan dapat menjalankan proses pendapatan yang baik. Dengan adanya sistem informasi akuntansi pendapatan, karyawan memiliki prosedur kerja yang jelas sehingga diharapkan dapat meningkatkan kinerja perusahaan dan menghindari terjadinya penyimpangan atas aktivitas penerimaan pendapatan yang terjadi. Aktivitas penjualan tidak hanya sekedar menjual saja, tetapi harus tahu bagaimana aktivitas tersebut dapat tercatat dengan baik, bagaimana memperoleh konsumen, mengadakan pemesanan, sampai barang pesanan diterima oleh konsumen dengan baik. 


\section{LANDASAN TEORI}

\section{Sistem Informasi Akuntansi}

Sistem adalah suatu kesatuan yang terdiri dari komponen yang dihubungkan bersama untuk memudahkan aliran informasi, materi, atau energi untuk mencapai suatu tujuan. Menurut Mulyadi (2010:2), sistem adalah sekelompok unsur yang erat berhubungan satu dengan yang lainnya, yang berfungsi bersama-sama untuk mencapai tujuan tertentu. Sedangkan menurut Yakup (2012:1), sistem adalah suatu jaringan kerja dari prosedur-prosedur yang berhubungan, terkumpul bersama-sama untuk melakukan suatu kegiatan atau tujuan tertentu.

Midjan (2008:10) sistem informasi merupakan kombinasi manusia, fasilitas atau alat teknologi, media, prosedur dan pengendalian yang bermaksud menata jaringan komunikasi atau transaksi-transaksi tertentu dan rutin, membantu manajemen dan pemakai intern dan ekstern dan menyediakan dasar pengambilan keputusan yang tepat. Sedangkan menurut Mulyanto (2009:4) sistem informasi adalah suatu kerangka kerja dengan mana sumber daya (Manusia, Komputer) dikoordinasikan untuk mengubah masukan (data) menjadi keluaran guna mencapai sasaran perusahaan. Akuntansi merupakan suatu alat komunikasi bagi setiap perusahaan. Akuntansi adalah suatu proses mencatat, mengklasifikasi, meringkas, mengolah dan menyajikan data, transaksi serta kejadian yang berhubungan dengan keuangan sehingga dapat digunakan oleh orang yang menggunakannya dengan mudah dimengerti untuk pengambilan suatu keputusan serta tujuan lainnya. Tujuan akhir dari kegiatan akuntansi adalah penerbitan laporan-laporan keuangan. Laporan-laporan keuangan tersebut merupakan suatu informasi. Sistem informasi yang berbasis komputer sekarang dikenal dengan istilah sistem informasi akuntansi atau SIA (Accounting information system atau AIS).

Warren (2008:10) secara umum, akuntansi merupakan sistem informasi yang menghasilkan laporan kepada pihak-pihak yang berkepentingan mengenai aktivitas ekonomi perusahaan. Sedangkan menurut Mulyadi (2010:3) akuntansi adalah organisasi formulir, catatan, dan laporan yang dikoordinasi sedemikian rupa untuk menyediakan informasi keuangan yang dibutuhkan oleh manajemen guna memudahkan pengelolaan perusahaan. Krismiaji (2010:3) sistem informasi akuntansi adalah sebuah sistem yang memproses data dan transaksi guna menghasilkan informasi yang bermanfaat untuk merencanakan, mengendalikan dan mengoperasikan bisnis. Widjajanto (2008:4) mendefinisikan sistem informasi akuntansi sebagai susunan berbagai formulir catatan, peralatan, termasuk komputer dan perlengkapannya serta alat komunikasi, tenaga pelaksananya, dan laporan yang terkoordinasikan secara erat yang didesain untuk mentransformasikan data keuangan menjadi yang dibutuhkan manajemen. Dengan demikian sistem informasi akuntansi dapat diartikan sebagai suatu kegiatan yang terintegrasi yang menghasilkan laporan dalam bentuk data transaksi bisnis yang diolah dan disajikan sehingga menjadi sebuah laporan keuangan yang memiliki arti bagi pihak yang membutuhkannya.

Menurut Romney (2009:7) ada enam karakteristik yang membuat suatu informasi berguna dan memiliki arti bagi pengambilan keputusan sebagai berikut :

1. Relevan, informasi harus memiliki kebenaran sehingga tidak menimbulkan keraguan bagi pengguna dan dapat digunakan secara tepat untuk membuat suatu keputusan.

2. Andal, informasi harus memiliki keandalan yang tinggi sehingga terbebas dari kesalahan dan penyimpangan dalam aktivitas perusahaan.

3. Lengkap, suatu informasi harus memiliki kelengkapan dan tidak menghilangkan aspek-aspek penting dari kejadian yang merupakan dasar masalah atau aktivitas yang diukurnya.

4. Tepat waktu, setiap informasi harus diberikan pada saat yang tepat dan cepat, sehingga penting untuk digunakan dalam pengambilan keputusan.

5. Dapat dipahami, informasi yang disajikan secara jelas akan memudahkan orang dalam untuk memahaminya.

6. Dapat diverifikasi, informasi dapat diverifikasi jika dua orang dengan pengetahuan yang baik, bekerja secara independen dan masing-masing akan menghasilkan informasi yang sama.

\section{Tujuan Dan Fungsi Sistem Informasi Akuntansi}

Menurut Jogianto (2008:54) tujuan dan fungsi utama dalam penyusunan sistem informasi akuntansi adalah sebagai berikut :

a. Untuk memperbaiki informasi yang diberikan oleh sistem dalam kualitas, ketepatan waktu, dan struktur dari informasi tersebut.

b. Untuk memperbaiki pengendalian akuntansi dan pengecekan intern, yang berarti memperbaiki daya andal informasi akuntansi dan menyediakan catatan yang lengkap sebagai pertanggungjawaban dalam melindungi harta perusahaan.

c. Untuk menurunkan biaya dalam menyelenggarakan catatan akuntansi. 


\section{Siklus Transaksi Sistem Informasi Akuntansi}

Pada umumnya, transaksi keuangan adalah kegiatan ekonomi yang mempengaruhi aktiva dan ekuitas perusahaan dicerminkan dalam akun-akunnya, dan diukur dalam kesatuan mata uang. Transaksi keuangan yang paling umum adalah pertukaran ekonomi dengan pihak eksternal. Hal ini termasuk penjualan barang atau jasa, pembelian persediaan, pembebasan kewajiban keuangan, dan penerimaan kas dari pelanggan. Transaksi keuangan adalah kegiatan bisnis umum yang terjadi secara rutin. Misalnya, ribuan transaksi dari satu jenis tertentu (penjualan ke pelanggan) bisa terjadi setiap hari. Untuk menghadapi volume yang besar tersebut secara efisiensi perusahaan mengelompokkan jenis- jenis transaksi yang sama ke dalam siklus- siklus transaksi. Romney (2009:85) ada lima siklus sistem informasi akuntansi, yaitu :

1. Siklus pendapatan, kejadian-kejadian yang berkaitan dengan pendistribusian barang dan jasa ke entitas- entitas lain dan pengumpulan pembayaran-pembayaran yang berkaitan.

2. Siklus Pengeluaran, kejadian- kejadian yang berkaitan dengan perolehan barang dan jasa dari entitasentitas lain dan pelunasan kewajiban-kewajiban yang berkaitan.

3. Siklus produksi, kejadian- kejadian yang berkaitan dengan pengubahan sumber daya menjadi barang dan jasa.

4. Siklus penggajian sumber daya manusia, kejadian- kejadian yang berkaitan dengan penggajian karyawan.

5. Siklus keuangan, kejadian- kejadian yang berkaitan dengan perolehan dan menejemen dana- dana modal, termasuk kas.

\section{Sistem Penerimaan Pendapatan Dari Penjualan Tunai}

Mulyadi (2010:455) penjualan tunai adalah penjualan yang dilakukan oleh perusahaan dengan cara pelanggan melakukan pembayaran lunas terhadap barang yang akan dibeli baik setelah pelanggan menerima barang maupun sebelum diserahkan. Mulyadi (2010:456) sistem penerimaan pendapatan dari penjualan tunai dibagi menjadi tiga prosedur, yaitu :

\section{Fungsi Yang Terkait Dalam Sistem Penerimaan Pendapatan Penjualan Tunai}

Menurut Mulyadi (2010:462) terdapat beberapa fungsi yang terkait dalam sistem penerimaan pendapatan dari penjualan tunai, yaitu :

1. Fungsi Penjualan

2. Fungsi Kas

3. Fungsi Gudang

4. Fungsi Pengiriman

5. Fungsi Akuntansi

\section{Dokumen Yang Digunakan Dalam Sistem Penerimaan Pendapatan Penjualan Tunai}

Mulyadi (2010:363), dokumen yang digunakan dalam sistem penerimaan pendapatan dari penjualan tunai adalah :

1. Faktur penjualan tunai

Dokumen ini digunakan untuk merekam berbagai informasi yang diperlukan oleh manajemen mengenai transaksi penjualan tunai. Faktur penjualan tunai diisi oleh fungsi penjualan yang berfungsi sebagai pengantar pembayaran oleh pembeli kepada fungsi kas dan sebagai dokumen sumber untuk pencatatan transaksi penjualan tunai ke jurnal penjualan.

2. Pita register kas (cash register tape)

Dokumen ini dihasilkan oleh fungsi kas dengan mengoperasikan mesin register kas (cash register). Pita register kas ini merupakan bukti penerimaan kas yang dikeluarkan oleh fungsi kas dan merupakan dokumen pendukung faktur penjualan tunai yang dicatat dalam jurnal penjualan.

3. Credit card sales slip

Dokumen yang dicetak oleh credit card center bank yang menerbitkan kartu kredit dan diserahkan kepada perusahaan (disebut merchant) yang menjadi anggota kartu kredit. Bagi perusahaan yang menjual barang atau jasa, dokumen ini diisi oleh fungsi kas dan berfungsi sebagai alat untuk menagih uang tunai dari bank yang mengeluarkan kartu kredit, untuk transaksi penjualan yang telah dilakukan kepada pemegang kartu kredit.

4. Bill of lading

Dokumen ini merupakan bukti penyetoran barang dari perusahaan penjualan barang kepada perusahaan angkutan umum. Dokumen ini digunakan oleh fungsi pengiriman dalam penjualan Custumer Order Delivery (COD) dan penyerahan barangnya dilakukan oleh perusahaan angkutan umum. 
5. Faktur penjualan $C O D$

Dokumen ini digunakan untuk merekam penjualan Custumer Order Delivery (COD). Tembusan faktur penjualan $C O D$ diserahkan kepada pelanggan melalui bagian angkutan perusahaan, kantor pos, atau perusahaan angkutan umum dan dimintakan tanda tangan penerimaan barang dari pelanggan sebagai bukti telah diterimanya barang oleh pelanggan. Tembusan faktur penjualan COD digunakan oleh perusahaan untuk menagih kas yang harus dibayar oleh pelanggan pada saat penyerahan barang yang dipesan oleh pelanggan.

6. Bukti setor bank

Dokumen ini dibuat oleh fungsi kas sebagai bukti penyetoran kas ke bank. Bukti setor bank diserahkan oleh fungsi kas kepada fungsi akuntansi, dan dipakai oleh fungsi akuntansi sebagai dokumen sumber untuk pencatatan transaksi penerimaan pendapatan dari penjualan tunai ke dalam jurnal penerimaan kas.

7. Rekapitulasi harga pokok penjualan Dokumen ini digunakan oleh fungsi akuntansi untuk meringkas harga pokok produk yang dijual selama satu periode. Dokumen ini digunakan oleh fungsi akuntansi sebagai dokumen pendukung bagi pembuatan bukti memorial untuk mencatat harga pokok produk yang dijual.

\section{Catatan Akuntansi Yang Digunakan Dalam Sistem Penerimaan Pendapatan Penjualan Tunai}

Menurut Mulyadi (2010:468), catatan akuntansi yang digunakan dalam sistem penerimaan pendapatan dari penjualan tunai adalah :

1. Jurnal penjualan Jurnal penjualan digunakan oleh fungsi akuntansi untuk mecatat dan meringkas data penjualan.

2. Jurnal penerimaan kas Jurnal penerimaan kas digunakan oleh fungsi akuntansi untuk mencatat penerimaan kas dari penjualan tunai.

3. Jurnal umum Jurnal umum digunakan oleh fungsi akuntansi untuk mencatat harga pokok produk yang dijual.

4. Kartu persediaan kartu persediaan digunakan oleh fungsi akuntansi untuk mengawasi mutasi dan persediaan barang di gudang.

5. Kartu gudang

Kartu gudang digunakan oleh fungsi gudang untuk mencatat mutasi dan persediaan barang yang disimpan di gudang.

\section{Jaringan Prosedur Yang Membentuk Sistem Penerimaan Pendapatan Penjualan Tunai}

Menurut Mulyadi (2010:469) jaringan prosedur yang membentuk sistem penerimaan pendapatan dari penjualan tunai adalah sebagai berikut :

1. Prosedur order penjualan

Dalam prosedur ini fungsi penjualan menerima order dari pembeli dan membuat faktur penjualan tunai untuk memungkinkan pembeli melakukan pembayaran harga barang ke fungsi kas dan untuk memungkinkan fungsi gudang dan fungsi pengiriman menyiapkan barang yang akan diserahkan kepada pembeli.

2. Prosedur penerimaan kas

Dalam prosedur ini fungsi kas menerima pembayaran harga barang dari pembeli dan memberikan tanda pembayaran (berupa pita register kas dan cap "lunas") kepada pembeli untuk memungkinkan pembeli tersebut melakukan pengambilan barang yang dibelinya dari fungsi pengiriman.

3. Prosedur penyerahan barang

Dalam prosedur ini fungsi pengiriman menyerahkan barang kepada pembeli.

4. Prosedur pencatatan penjualan tunai

Dalam prosedur ini fungsi akuntansi melakukan pencatatan transaksi penjualan tunai dalam jurnal penjualan dan penerimaan kas. Fungsi akuntansi juga mencatat berkurangnya persediaan barang yang dijual dalam kartu persediaan.

5. Prosedur penyetoran kas ke bank

Dalam prosedur ini fungsi kas menyetorkan kas yang diterima dari penjualan tunai ke bank dalam jumlah penuh.

6. Prosedur pencatatan penerimaan kas

Dalam prosedur ini, fungsi akuntansi mencatat penerimaan kas ke dalam jurnal penerimaan kas berdasar bukti setor bank yang diterima dari bank melalui fungsi kas.

7. Prosedur pencatatan harga pokok penjualan 
Dalam prosedur ini, fungsi akuntansi membuat rekapitulasi harga pokok penjualan berdasarkan data yang dicatat dalam kartu persediaan. Berdasarkan rekapitulasi harga pokok penjualan ini, fungsi akuntansi membuat bukti memorial sebagai dokumen sumber untuk pencatatan harga pokok penjualan ke dalam jurnal umum.

\section{METODOLOGI}

Jenis penelitian adalah deskriptif komparati tif (Sugiyono, 2013:14) yaitu data yang berupa penjelasan atau pernyataan yang tidak berbentuk angka. Penelitian deskriptif kualitatif ini digunakan untuk mencari fakta dengan interprestasi yang tepat dan tujuannya adalah untuk mencari deskripsi dan gambaran yang sistematis dan akurat mengenai faktor-faktor, sifat-sifat serta hubungan antara fenomena yang diselidiki.

Metode analisis yang digunakan dalam penelitian ini adalah metode komparatif. Menurut Nasir (2009:58) penelitian komparatif adalah sejenis penelitian deskriptif yang ingin mencari jawaban secara mendasar tentang sebab-akibat, dengan menganalisis faktor-faktor penyebab terjadinya ataupun munculnya suatu fenomena tertentu. Penelitian komparatif merupakan jenis penelitian yang digunakan untuk membandingkan antara dua kelompok atau lebih dari suatu variabel.

Tabel 1. Perbandingan Penerapan Sistem Informasi Akuntansi Pendapatan Penjualan Tunai

\begin{tabular}{|c|c|c|c|c|}
\hline No & Uraian & $\begin{array}{c}\text { PT. Maxindo Karya } \\
\text { Selaras Kota Bengkulu }\end{array}$ & Mulyadi (2010:455) & Ket \\
\hline 1 & $\begin{array}{l}\text { Sistem } \\
\text { penerimaan } \\
\text { pendapatan dari } \\
\text { penjualan tunai }\end{array}$ & & $\begin{array}{l}\text { 1. Prosedur Penerimaan kas dari } \\
\text { Over -the Counter Sale } \\
\text { 2. Prosedur penerimaan kas dari } \\
\text { COD Sale } \\
\text { 3. Prosedur penerimaan kas dari } \\
\text { Credit card sale }\end{array}$ & $\begin{array}{l}\text { Sesuai/ } \\
\text { Tidak } \\
\text { sesuai }\end{array}$ \\
\hline 2 & $\begin{array}{l}\text { Fungsi yang } \\
\text { terkait }\end{array}$ & & $\begin{array}{ll}\text { 1. } & \text { Fungsi Penjualan } \\
\text { 2. } & \text { Fungsi Kas } \\
\text { 3. } & \text { Fungsi Gudang } \\
\text { 4. } & \text { Fungsi Pengiriman } \\
\text { 5. } & \text { Fungsi Akuntansi }\end{array}$ & $\begin{array}{l}\text { Sesuai/ } \\
\text { Tidak } \\
\text { sesuai }\end{array}$ \\
\hline 3 & $\begin{array}{l}\text { Dokumen yang } \\
\text { digunakan }\end{array}$ & & $\begin{array}{ll}\text { 1. } & \text { Faktur penjualan tunai } \\
\text { 2. } & \text { Pita register kas } \\
\text { 3. } & \text { Credit card sales slip } \\
\text { 4. } & \text { Bill of lading } \\
\text { 5. } & \text { Faktur penjualan } C O D \\
\text { 6. } & \text { Bukti setor bank } \\
\text { 7. } & \text { Rekapitulasi HPP }\end{array}$ & $\begin{array}{l}\text { Sesuai/ } \\
\text { Tidak } \\
\text { sesuai }\end{array}$ \\
\hline 4 & $\begin{array}{l}\text { Catatan } \\
\text { akuntansi yang } \\
\text { digunakan }\end{array}$ & & $\begin{array}{l}\text { 1. Jurnal penjualan } \\
\text { 2. Jurnal penerimaan kas } \\
\text { 3. Jurnal umum } \\
\text { 4. Kartu persediaan } \\
\text { 5. Kartu gudang }\end{array}$ & $\begin{array}{l}\text { Sesuai/ } \\
\text { Tidak } \\
\text { sesuai }\end{array}$ \\
\hline 5 & $\begin{array}{l}\text { Jaringan } \\
\text { prosedur sistem } \\
\text { penerimaan } \\
\text { pendapatan }\end{array}$ & & $\begin{array}{l}\text { 1. Prosedur order penjualan } \\
\text { 2. prosedur penerimaan kas } \\
\text { 3. prosedur penyerahan barang } \\
\text { 4. prosedur pencatatan penjualan } \\
\text { tunai } \\
\text { 5. prosedur penyetoran kas ke } \\
\text { bank } \\
\text { 6. prosedur pencatatan } \\
\text { 7. penerimaan kas } \\
\text { 7. prosedur pencatatan HPP } \\
\end{array}$ & $\begin{array}{l}\text { Sesuai/ } \\
\text { Tidak } \\
\text { sesuai }\end{array}$ \\
\hline
\end{tabular}




\section{HASIL PENELITIAN DAN PEMBAHASAN}

PT. Maxindo Karya Selaras merupakan perusahaan bergerak dibidang transportasi batu bara seperti hauling, trading, dan loading batu bara. Untuk memperluas jaringan usahanya, PT. Maxindo Karya Selaras bekerjasama dengan tiga perusahaan lokal yang sangat berpengalaman dibidang batu bara, material, maupun kontraktor yaitu PT. Atlas Citra Selaras, PT. Rico Putra Selatan dan PT. Selamat Group Perkasa. PT. Maxindo Karya Selaras langsung melakukan pembelian batu bara di tambang PT. IRSA dan langsung hauling serta loading sendiri. Saat ini PT. Maxindo Karya Selaras hanya menjual batu bara kepada Semen Padang dengan kontrak 2 tongkang dengan kapasitas 7.500 MT setiap bulannya. Selain fokus pada bisnis tersebut, PT. Maxindo Karya Selaras juga menerima permintaan material yang biasa dipesan oleh kontraktor-kontraktor yang sedang melakukan proyek dalam kota, seperti pembuatan jalan dan lain-lain.

\section{Sistem Penerimaan pendapatan Dari Penjualan Tunai Pada PT. Maxindo Karya Selaras Kota Bengkulu}

PT. Maxindo Karya Selaras Kota Bengkulu merupakan salah satu perusahaan lokal yang bergerak dibidang penjualan batu bara. Sistem penerimaan pendapatan PT. Maxindo Karya Selaras adalah penjualan batu bara secara tunai. Dalam penjualan batu bara secara tunai PT. Maxindo Karya Selaras Kota Bengkulu menggunakan prosedur Cash on Delivery Order sale (COD), yaitu transaksi penjualan yang melibatkan perusahaan angkutan laut atau perkapalan. Dalam penyerahan batu bara kepada pembeli PT. Maxindo Karya Selaras Kota Bengkulu menggunakan kapal Tongkang sebagai alat untuk mengirim batu bara kepada pembeli.

Berikut tahap-tahap penjualan batu bara secara tunai dengan menggunakan COD pada PT. Maxindo Karya Selaras Kota Bengkulu :

1. Pihak pembeli mengecek barang bersama Surveyor apakah kualitas dan kuantitas kalori batu bara telah sesuai yang diminta oleh pihak pembeli.

2. Memastikan barang yang diminta telah sesuai, maka pihak pembeli dan pihak penjual melakukan deal kontrak. Pada kontrak jual beli ini PT. Asia Pasific Mining Resources (APMR) di sepakati sebagai pihak pembiayaan.

3. Pihak pembeli melakukan pembayaran down payment sebesar $50 \%$.

4. PT. Maxindo Karya Selaras selaku pihak penjual menerima down payment dari pihak pembeli, maka PT. Maxindo Karya Selaras melakukan pembayaran kepada pihak tambang sebesar 50\%.

5. PT. Maxindo Karya Selaras melakukan hauling (pengangkutan) batu bara dari Tambang menuju ke stok file Pulau Baai.

6. Setelah dipastikan stok batu bara di stok file Pulau Baai sudah cukup $( \pm 7500 \mathrm{MT})$ Pihak PT. Maxindo Karya Selaras mengkonfirmasikan kepada pihak pembeli bahwa akan dilakukan pengiriman barang.

7. Sebelum proses batu bara dikirim, pihak pembeli melakukan pembayaran kedua sebesar 30\%, dan pihak penjual juga melakukan pembayaran pelunasan kepada pihak tambang.

8. PT. Maxindo Karya Selaras melakukan loading (pengapalan), biasanya loading dengan kapasitas 7.500MT memerlukan waktu normal sekitar 18 jam.

9. Setelah dipastikan loading selesai, maka pihak pembeli dan penjual menandatangani final draft yang dikeluarkan oleh Surveyor.

10. Setelah semua dokumen selesai, pihak penjual mengirimkan invoice dan dokumen lainnya melalui jasa pengiriman kepada pihak pembeli untuk pelunasan pembayaran. 


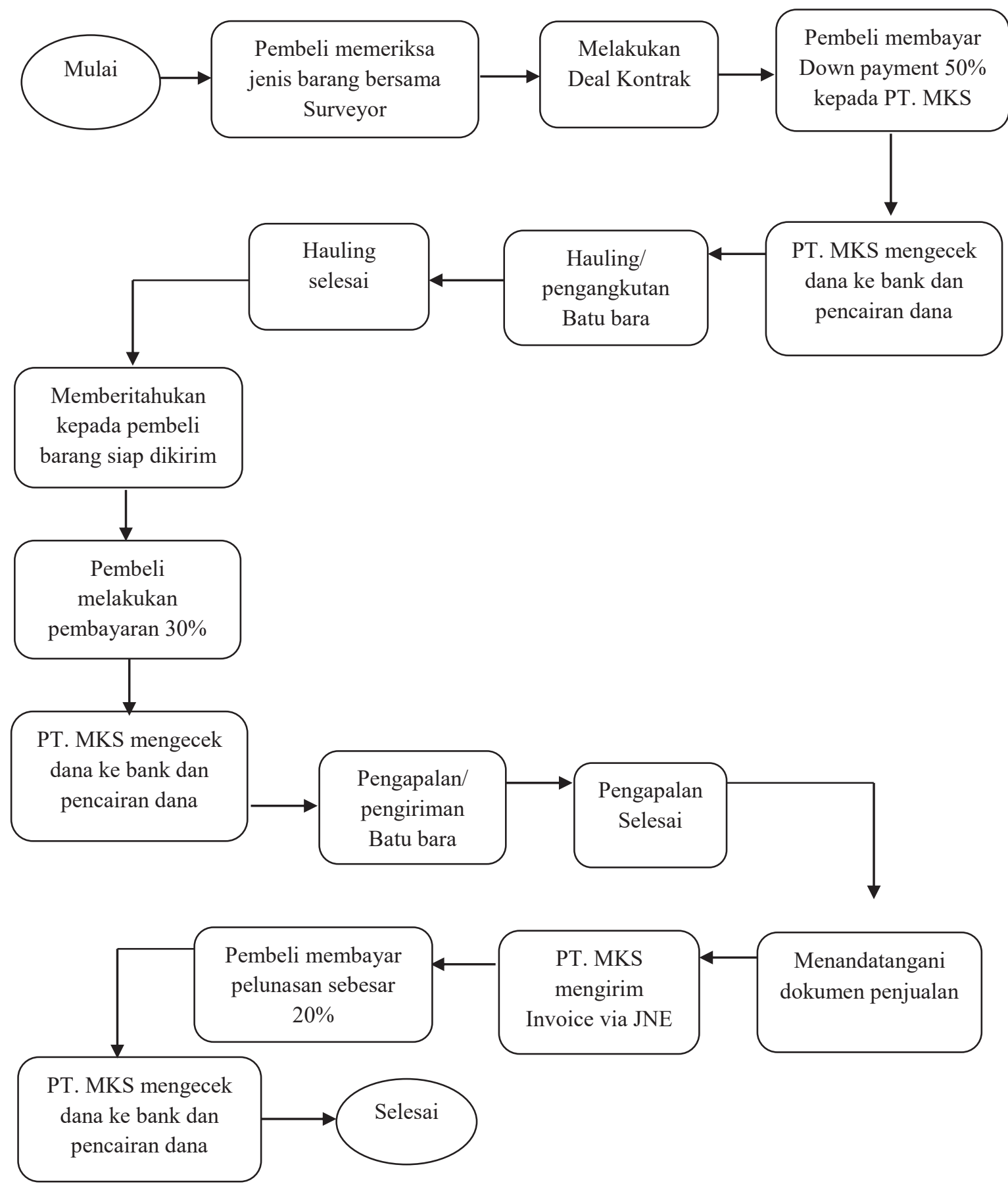

Gambar 1. Sistem Penerimaan Pendapatan PT. Maxindo Karya Selaras Kota Bengkulu

Fungsi Yang Terkait Dalam Sistem Penerimaan Pendapatan Dari Penjualan Tunai Pada PT. Maxindo Karya Selaras Kota Bengkulu

Adapun fungsi atau bagian yang terkait dalam sistem penerimaan pendapatan penjualan tunai batu bara pada PT. Maxindo Karya Selaras Kota Bengkulu adalah sebagai berikut :

1. Bagian Penjualan

a. Menerima order dari buyer

b. Melaporkan kepada bagianOperasional tentang rencana order yang diterima 
c. Setelah mendapatkan otorisasi dari bagian Operasional, bagian penjualan membuat booking order yang pertama dan diberikan ke bagian administrasi dan lembar kedua ke bagian Operasional untuk melakukan prosedur selanjutnya.

d. Menerima dokumen-dokumen penjualan yang diberikan oleh bagian administrasi. Dokumen tersebut antara lain invoice, bill of lading (B/L), Surat keterangan Asal Barang (SKAB), Surat Keterangan Pembayaran Iuran (SKPI).

e. Setelah ada pemberitahuan dari bagian Operasional bahwa barang sudah siap dikirim, maka bagian ini akan melakukan pengiriman melalui jasa pengiriman barang.

f. Mengirimkan dokumen-dokumen penjualan melalui jasa pengiriman.

g. Menerima bukti kirim dokumen dan menyerahkannya ke bagian administrasi.

2. Bagian Akuntansi, dalam Transaksi penjualan tunai batu bara, fungsi ini bertanggung jawab menerima kas dari hasil penjualan batu bara dan mencatat penerimaan kas dari bukti setor bank yang diterima dari pembeli.

\section{Dokumen Yang Digunakan Dalam Sistem Penerimaan Pendapatan Penjualan Tunai Pada PT. Maxindo Karya Selaras Kota Bengkulu}

Dalam sistem penerimaan pendapatan dari penjualan tunai batu bara, dokumen yang digunakan pada PT. Maxindo Karya Selaras Kota Bengkulu adalah sebagai berikut :

1. Sales Contract

Sales Contract adalah surat perjanjian antara penjual dan pembeli untuk melakukan jual beli batu bara sesuai persyaratan yang telah disepakati bersama.

2. Booking Order

Booking Order adalah dokumen yang berisi tentang spesifikasi yang di inginkan buyer. Dokumen ini menjelaskan tentang bentuk, ukuran, kualitas dan kuantitas batu bara yang digunakan sesuai permintaan buyer.

3. Invoice (Faktur penjualan)

Invoice atau Faktur penjualan merupakan keterangan tentang jumlah batu bara dan harga batu bara yang dijual kepada pembeli.

4. Bill of Lading

Bill of Lading (B/L) adalah bukti tanda terima barang, bukti kepemilikan barang yang dikeluarkan oleh perusahaan pelayaran (perusahaan perkapalan) sebagai bukti adanya perjanjian pengangkutan barang.

5. Surat Keterangan Asal Barang (SKAB)

SKAB merupakan surat keterangan yang dibuat oleh bagian tambang untuk menyatakan asal barang yang akan dijual.

6. Bukti Setor Bank

Bukti setor bank adalah bukti yang diterima dari bank dari penyetoran dana dari rekening suatu bank.

\section{Catatan Akuntansi Yang Digunakan Dalam Sistem Penerimaan Pendapatan Penjualan Tunai Pada PT. Maxindo Karya Selaras Kota Bengkulu}

Adapun catatan akuntansi yang digunakan dalam sistem penerimaan pendapatan penjualan tunai batu bara pada PT. Maxindo Karya Selaras Kota Bengkulu adalah sebagai berikut :

1. Jurnal Penjualan

Jurnal penjualan ini digunakan untuk mencatat transaksi penjualan tunai batu bara yang dilakukan. Pencatatan dalam jurnal ini bersumber dari bukti kirim barang yang diterima oleh bagian penjualan.

2. Jurnal Penerimaan Kas

Jurnal penerimaan kas ini digunakan oleh bagian Accounting Chief untuk mencatat penerimaan kas. Dalam hal ini untuk mencatat penerimaan hasil dari penjualan batu bara yang dilakukan, pencatatan bersumber dari bukti setor bank yang diterima dari pembayaran pembeli.

3. Jurnal Umum

Merupakan catatan akuntansi yang digunakan untuk mencatat transaksi dalam perusahaan selain yang dicatat dalam jurnal penerimaan kas dan jurnal penjualan. Dalam sistem penjualan tunai batu bara ini jurnal umum digunakan untuk mencatat harga pokok produk yang dijual selama periode tertentu. 
Jaringan prosedur Yang Membentuk Sistem Penerimaan pendapatan Penjualan Tunai Pada PT. Maxindo Karya Selaras Kota Bengkulu

Adapun jaringan prosedur yang membentuk sistem penerimaan pendapatan dari penjualan tunai batu bara pada PT. Maxindo Karya Selaras Kota Bengkulu adalah :

1. Prosedur order penjualan

Dalam prosedur ini, bagian penjualan menerima order dari pembeli berupa pesanan batu bara dengan kualitas dan kuantitas yang diinginkan. Kemudian antara penjual dan pembeli melakukan deal kontrak yang telah disepakati bersama.

2. Prosedur penyerahan barang

Dalam prosedur ini, bagian penjualan menyerahkan barang kepada pembeli ketika jumlah stok batu bara yang dipesan sudah cukup. Penyerahan barang dilakukan melalui transportasi laut yaitu kapal Tongkang.

3. Prosedur pencatatan dan penerimaan kas

Dalam prosedur ini bagian Accounting Chief menerima dan mencatat pembayaran dari pembeli yang bersumber dari bukti setor bank karena pembayaran dilakukan dengan cara pembeli mentransfer dana ke rekening perusahaan.

Penerapan sistem informasi akuntansi pendapatan pada PT. Maxindo Karya Selaras Kota Bengkulu merupakan rangkaian dari sistem penjualan tunai batu bara pada pelanggan khususnya pesanan dari PT. Semen Padang. Dengam menganalisis sistem informasi akuntansi pendapatan pada PT. Maxindo Karya Selaras Kota Bengkulu dapat diketahui sesuai atau tidak sesuai dari penerapan sistem informasi akuntansi pada PT. maxindo Karya Selaras Kota Bengkulu dengan teori Mulyadi. Hasil analisis sistem informasi akuntansi pendapatan pada PT. Maxindo Karya Selaras Kota Bengkulu dapat dketahui pada tabel di bawah ini.

Tabel 2. Perbandingan Penerapan Sistem Informasi Akuntansi Pendapatan Penjualan Tunai Pada PT. Maxindo Karya Selaras Kota Bengkulu dengan Teori Mulyadi.

\begin{tabular}{|c|c|c|c|c|}
\hline No & Uraian & $\begin{array}{l}\text { PT.MKS Kota } \\
\text { Bengkulu }\end{array}$ & Mulyadi (2010:455) & Ket \\
\hline 1 & $\begin{array}{l}\text { Sistem } \\
\text { penerimaan } \\
\text { pendapatan dari } \\
\text { penjualan tunai }\end{array}$ & $\begin{array}{l}\text { Prosedur } \\
\text { Penerimaan } \quad \text { Kas } \\
\text { dari COD Sale }\end{array}$ & $\begin{array}{l}\text { 1. Prosedur Penerimaan kas dari Over -the } \\
\text { Counter Sale } \\
\text { 2. Prosedur penerimaan kas dari COD Sale } \\
\text { 3. Prosedur penerimaan kas dari Credit } \\
\text { card sale }\end{array}$ & $\begin{array}{l}\text { Sesua } \\
\text { i }\end{array}$ \\
\hline 2 & $\begin{array}{l}\text { Fungsi yang } \\
\text { terkait }\end{array}$ & $\begin{array}{l}\text { Bagian Penjualan } \\
\text { Bagian Akuntansi }\end{array}$ & $\begin{array}{ll}\text { 1. } & \text { Fungsi Penjualan } \\
\text { 2. } & \text { Fungsi Kas } \\
\text { 3. } & \text { Fungsi Gudang } \\
\text { 4. } & \text { Fungsi Pengiriman } \\
\text { 5. } & \text { Fungsi Akuntansi }\end{array}$ & $\begin{array}{l}\text { Sesua } \\
\mathrm{i}\end{array}$ \\
\hline 3 & $\begin{array}{ll}\text { Dokumen } & \text { yang } \\
\text { digunakan } & \end{array}$ & $\begin{array}{l}\text { Sales Contact } \\
\text { Booking Order } \\
\text { Invoice } \\
\text { Bill of lading } \\
\text { SKAB } \\
\text { Bukti setor bank }\end{array}$ & $\begin{array}{l}\text { 1. } \\
\text { 2. Paktur penjualan tunai } \\
\text { 3. } \text { Credit card sales slip } \\
\text { 4. Bill of lading } \\
\text { 5. Faktur penjualan COD } \\
\text { 6. Bukti setor bank } \\
\text { 7. } \text { Rekapitulasi HPP }\end{array}$ & $\begin{array}{l}\text { Sesua } \\
\text { i }\end{array}$ \\
\hline 4 & $\begin{array}{l}\text { Catatan akuntansi } \\
\text { yang digunakan }\end{array}$ & $\begin{array}{l}\text { Jurnal penjualan } \\
\text { Jurnal penerimaan } \\
\text { kas } \\
\text { Jurnal umum }\end{array}$ & $\begin{array}{l}\text { 1. Jurnal penjualan } \\
\text { 2. Jurnal penerimaan kas } \\
\text { 3. Jurnal umum } \\
\text { 4. Kartu persediaan } \\
\text { 5. Kartu gudang }\end{array}$ & $\begin{array}{l}\text { Sesua } \\
\text { i }\end{array}$ \\
\hline 5 & $\begin{array}{l}\text { Jaringan prosedur } \\
\text { sistem } \\
\text { penerimaan } \\
\text { pendapatan }\end{array}$ & $\begin{array}{l}\text { Prosedur order } \\
\text { penjualan } \\
\text { Prosedur } \\
\text { penyerahan barang } \\
\text { Prosedur } \\
\text { pencatatan dan } \\
\text { penerimaan kas }\end{array}$ & $\begin{array}{l}\text { 1. Prosedur order penjualan } \\
\text { 2. prosedur penerimaan kas } \\
\text { 3. prosedur penyerahan barang } \\
\text { 4. prosedur pencatatan penjualan tunai } \\
\text { 5. prosedur penyetoran kas ke bank } \\
\text { 6. prosedur pencatatan penerimaan kas } \\
\text { 7. prosedur pencatatan HPP }\end{array}$ & $\begin{array}{l}\text { Sesua } \\
\mathrm{i}\end{array}$ \\
\hline
\end{tabular}


Tabel 2 di atas menunjukkan perbandingan antara sistem informasi akuntansi pendapatan yang diterapkan pada PT. Maxindo Karya Selaras Kota Bengkulu dengan teori yang disampaikan Mulyadi adalah sebagai berikut :

1. Sistem penerimaan pendapatan dari penjualan tunai sistem yang digunakan dalam penerimaan pendapatan penjualan tunai batu bara pada PT. Maxindo Karya Selaras Kota Bengkulu telah sesuai dengan teori Mulyadi. Pada teori Mulyadi sistem penerimaan pendapatan terbagi tiga prosedur yaitu :

a. Over the Counter Sale,yaitu transaksi yang dilakukan dengan cara pembeli datang dan langsung memilih barang yang akan dibeli serta melakukan pembayaran ke kasir dan menerima barang yang akan dibeli.

b. Cash on Delivery Order sale (COD sale),yaitu transaksi penjualan yang melibatkan perusahaan angkutan umum dengan cara penjual mengirim barang pesanan terlebih dahulu kepada pembeli dan ketika barang sudah sampai kepada pembeli maka pembeli melakukan pembayaran.

c. Credit Card Sale, yaitu pembayaran barang dari pembelian tunai yang dilakukan oleh pembeli dengan menggunakan kartu kredit.

Sistem penerimaan pendapatan dari penjualan tunai yang diterapkan pada PT. Maxindo Karya Selaras Kota Bengkulu menggunakanCash on Delivery Order sale (COD). Dimana COD merupakan transaksi penjualan dengan melibatkan perusahaan angkutan laut yaitu perusahaan perkapalan atau pelayaran. Dalam penyerahan batu bara kepada pembeli PT. Maxindo Karya Selaras Kota Bengkulu menggunakan kapal Tongkang sebagai alat untuk mengirim batu bara kepada pembeli. Pembayaran dilakukan dengan cara pembeli melakukan penyetoran (mentransfer) dana ke rekening perusahaan penjual berdasarkan nominal yang telah disepakati bersama, sistem penerimaan pendapatan dari penjualan tunai yang diterapkan pada PT. Maxindo Karya Selaras Kota Bengkulu telah sesuai dengan teori yang dikemukakan oleh Mulyadi, hanya saja sistem penerimaan pendapatan PT. Maxindo Karya Selaras Kota Bengkulu tidak menggunakan prosedur Over the Counter Sale dan Prosedur Credit Card Sale. Karena pembayaran tidak melalui Over the Counter sale dan tidak menggunakan Credit Card.

2. Fungsi yang terkait

Pada fungsi yang terkait telah sesuai antara teori Mulyadi dengan PT. Maxindo Karya Selaras Kota Bengkulu. Pada teori Mulyadi fungsi yang terkait dalam sistem penerimaan pendapatan penjualan tunai meliputi fungsi penjualan, fungsi kas, fungsi gudang, fungsi pengiriman, dan fungsi akuntansi. Sedangkan pada PT. Maxindo Karya Selaras Kota Bengkulu fungsi atau bagian yang sudah diterapkan yaitu bagian penjualan dan bagian akuntansi. Hanya saja pada PT. Maxindo Karya Selaras Kota Bengkulu masih adanya perangkapan fungsi yaitu antara fungsi penjualan dengan fungsi pengiriman yang dirangkap oleh satu bagian yaitu bagian penjualan. Fungsi kas dirangkap oleh bagian akuntansi.

3. Dokumen yang digunakan

Dokumen yang digunakan dalam sistem penerimaan pendapatan penjualan tunai batu bara pada PT. Maxindo Karya Selaras Kota Bengkulu telah sesuai dengan teori Mulyadi. Hanya saja dokumen yang digunakan pada PT. Maxindo Karya Selaras Kota Bengkulu lebih sedikit daripada sistem penerimaan pendapatan penjualan tunai menurut teori Mulyadi. Dokumen yang digunakan dalam sistem penerimaan pendapatan penjualan tunai batu bara pada PT. Maxindo Karya Selaras kota Bengkulu adalah sales contract yang berisikan tentang perjanjian jual beli batu bara dengan buyer, booking order yang berisikan tentang spesifikasi barang, invoice yang berfungsi sebagai faktur penjualan, bill of lading, SKAB dan bukti setor bank.

4. Catatan akuntansi yang digunakan

Pada catatan akuntansi yang digunakan terdapat kesesuaian antara teori Mulyadi dengan catatan yang ada pada PT. Maxindo Karya Selaras Kota Bengkulu. Pada teori Mulyadi catatan akuntansi yang digunakan meliputi jurnal penjualan, jurnal penerimaan kas, jurnal umum, kartu persediaan, dan kartu gudang. Sedangkan pada PT. Maxindo Karya Selaras Kota Bengkulu sudah memiliki dari beberapa catatan tersebut yaitu :

a. Jurnal penjualan, digunakan oleh bagian akuntansi untuk mencatat bukti kirim barang dari pengiriman barang yang dilakukan bagian penjualan.

b. Jurnal penerimaan kas, digunakan oleh bagian akuntansi untuk mencatat penerimaan kas dari penjualan tunai batu bara berdasarkan bukti setor bank.

c. Jurnal Umum, digunakan oleh bagian akuntansi untuk mencatat harga pokok produk yang dijual. Pencatatan ini dilakukan berdasarkan laporan yang diterima dari bagian penjualan.

5. Jaringan prosedur sistem penerimaan pendapatan 
Pada jaringan prosedur sistem penerimaan pendapatan terdapat kesesuaian antara teori Mulyadi dengan PT. Maxindo Karya Selaras Kota Bengkulu. Dimana pada teori Mulyadi jaringan prosedur sistem penerimaan pendapatan meliputi prosedur order penjualan, prosedur penerimaan kas, prosedur penyerahan barang, prosedur pencatatan penjualan tunai, prosedur penyetoran kas ke bank, prosedur pencatatan penerimaan kas, dan prosedur pencatatan HPP. Sedangkan pada PT. Maxindo Karya Selaras Kota Bengkulu memiliki beberapa dari prosedur tersebut yaitu prosedur order penjualan, prosedur penyerahan barang, prosedur pencatatan dan penerimaan kas.

Berdasarkan dari pembahasan tersebut, pada sistem akuntansi pendapatan dari penjualan tunai batu bara PT. Maxindo Karya Selaras Kota Bengkulu terdapat kelebihan dan kelemahan dalam menjalankan kegiatan usahanya, berikut kelebihan dan kelemahan yang terjadi pada PT. Maxindo Karya Selaras Kota Bengkulu.

1. Kelebihan yang terdapat pada sistem akuntansi pendapatan penjualan tunai pada PT. Maxindo Karya Selaras kota Bengkulu adalah :

a. Dalam melaksanakan transaksi penjualan tunai PT. Maxindo Karya Selaras Kota Bengkulu telah menggunakan dokumen-dokumen yang cukup lengkap sehingga kegiatan pengiriman batu bara dan pembayaran dari pelanggan yang dilakukan dapat berjalan dengan lancar.

b. Dalam transaksi sistem penerimaan pendapatan, jaringan prosedur pada PT. Maxindo Karya Selaras Kota Bengkulu sudah cukup memadai. Hal ini dapat dilihat dari penempatan bagian sudah berjalan dengan baik sesuai dengan tugas dan wewenang yang telah diberikan

2. Kelemahan yang terdapat pada sistem akuntansi pendapatan penjualan tunai pada PT. Maxindo Karya Selaras kota Bengkulu adalah :

a. Dalam sistem penerimaan pendapatan dari penjualan tunai batu bara pada PT. Maxindo Karya selaras Kota Bengkulu ini belum menggunakan catatatan akuntansi berupa kartu gudang dan kartu persediaan, perusahaan hanya menggunakan rekapitulasi jumlah barang berdasarkan laporan bagian penjualan saja.

b. Fungsi atau bagian yang diterapkan pada PT. Maxindo Karya selaras Kota Bengkulu masih adanya perangkapan fungsi yaitu antara fungsi penjualan dengan fungsi pengiriman yang dirangkap oleh satu bagian yaitu bagian penjualan. fungsi kas dirangkap oleh bagian akuntansi. Maka sebaiknya ada penambahan pada bagian fungsi pengiriman dan fungsi kas agar pengendalian intern perusahaan dapat berjalan dengan baik sehingga kekayaan perusahaan lebih terjaga.

\section{KESIMPULAN}

Sistem informasi akuntansi pendapatan yang ada pada PT. Maxindo Karya Selaras Kota Bengkulu meliputi sistem penerimaan pendapatan dari penjualan tunai, fungsi yang terkait, dokumen yang digunakan, catatan akuntansi yang digunakan, dan jaringan prosedur sistem penerimaan pendapatan. Penerapan sistem informasi akuntansi pendapatan pada PT. Maxindo Karya Selaras Kota Bengkulu terdapat kesesuaian pada sistem penerimaan pendapatan, fungsi yang terkait, dokumen yang digunakan, catatan akuntansi yang digunakan, dan jaringan prosedur sistem penerimaan pendapatan dengan teori Mulyadi, karena pada PT. Maxindo Karya selaras Kota Bengkulu terdapat proses pendapatan yang dimulai dari pesanan batu bara dari pembeli, pengiriman dan penagihan sudah berjalan dengan baik. Dalam melaksanakan transaksi penjualan tunai PT. Maxindo Karya Selaras Kota Bengkulu telah menggunakan dokumen-dokumen yang cukup lengkap sehingga kegiatan pengiriman batu bara dan pembayaran dari pelanggan yang dilakukan dapat berjalan dengan lancar.

\section{SARAN}

1. Untuk PT. Maxindo Karya Selaras Kota Bengkulu sebaiknya membuat katalog berupa spesifikasi kandungan batu bara agar mempermudah konsumen untuk memilih jenis dan kualitas yang diinginkan.

2. Fungsi atau bagian yang diterapkan pada PT. Maxindo Karya selaras Kota Bengkulu masih adanya perangkapan fungsi yaitu antara fungsi penjualan dengan fungsi pengiriman yang dirangkap oleh satu bagian yaitu bagian penjualan. Fungsi kas dirangkap oleh bagian akuntansi. Maka sebaiknya ada penambahan pada bagian fungsi pengiriman dan fungsi kas agar pengendalian intern perusahaan dapat berjalan dengan baik sehingga kekayaan perusahaan lebih terjaga. 


\section{DAFTAR PUSTAKA}

Jogianto, Ahmad, 2008, Sistem Informasi Akuntansi, Jakarta, Tiga Serangkai

Juliasmi, Mira, 2015, Analisis Penerapan Sistem Informasi Akuntansi Pendapatan Pada CV. Medy's Group Kota Bengkulu, Skripsi, Bengkulu, Universitas Dehasen Bengkulu

Krismiaji, 2010, Sistem Informasi Akuntansi, Yogyakarta, UPP AMP YKPN

Midgan, Nasution, 2008, Sistem Informasi Akuntansi, Edisi 9, Yogyakarta, Graha Ilmu Perkasa

Mulyadi, 2010, Sistem Akuntansi, Jakarta, Salemba Empat

Mulyanto, Anwar, 2009, Perancangan Sistem Informasi Akuntansi, Jakarta, Gramedia

Nasir, 2009, Metode Penelitian Pendidikan, Yogyakarta, ANDI

Romney, Marshall B, 2009, Accounting Information Systems, Jakarta, Salemba Empat

Sugiyono, Rahmat, 2013, Metode Penelitian Sosial, Bandung, Rieneka Cipta

Warren, Dkk, 2008, Pengantar Akuntansi, Edisi 21, Jakarta, Salemba Empat

Widjajanto, 2008, Sistem Informasi Akuntansi, Jakarta, Grasindo

Yakup, Alwi, 2012, Perancangan Sistem Informasi Akuntansi dan Aplikasinya, Klaten, Gava media 